\title{
The chemical composition of the tissue lost by obese patients on a reducing regimen
}

\author{
By R. PASSMORE, J. A. STRONG AND FIONA J. RITCHIE \\ Departments of Physiology and Medicine, University of Edinburgh, \\ and the Western General Hospital
}

(Received 2 October 1957)

The excess weight of obese people is not all attributable to fat. Adipose tissue contains cells with their nuclei, blood vessels and nerves in addition to fat. In most obese people there may be hypertrophy of skeletal and cardiac muscle, and perhaps of other organs, which have to support and move the increased mass of fat.

Keys \& Brožek (1953) introduced the term 'obesity tissue' to describe the material laid down in response to an excessive calorie intake. Obesity tissue is composed of fat, protein and other cell solids and water. It is described in chemical terms and so distinguished from adipose tissue, which is an anatomical term.

In this paper we present an analysis of the composition of obesity tissue lost by the seven patients on the reducing regimen described in the preceding paper (Strong, Passmore \& Ritchie, 1958).

\section{EXPERIMENTAL}

The changes in body protein were calculated by multiplying the measured nitrogen balance by $6 \cdot 25$. The calories derived from this loss were obtained by multiplying by 4 . I.*

The energy intake in the diet and the energy output in the daily activities were both measured (see below), the difference between the two giving the energy balance. On any reducing regimen energy output exceeds input and the deficit has to be made good by calories derived from fat and protein from the tissues. The calories derived from tissue protein having been determined from the $\mathrm{N}$ balance, the calories derived from tissue fat may be calculated by subtracting the tissue-protein calories from the total calorie deficit. The value, divided by $9 \cdot 3, \dagger$ gives the weight of fat lost. It can be assumed that the loss of carbohydrate is negligible. $f$ The loss of body water can then be obtained by subtracting the loss of tissue protein and tissue fat from the total loss of body-weight.

* For the weeks when the $\mathrm{N}$ balance was positive, the calorie value of the protein laid down was obtained by multiplying by the heat of combustion for protein, i.e. $5.3 \mathrm{Cal} / \mathrm{g}$.

$\dagger$ 'The heat of combustion of fat is used and not the Atwater factor of $9^{\circ} 0$ which includes a correction for incomplete absorption from the intestine.

I Total body carbohydrate is normally about $500 \mathrm{~g}$ and is kept remarkably constant even in starvation. A loss could never exceed $200 \mathrm{~g}$ and is probably much less. This would give a maximum average daily loss of $5 \mathrm{~g}$ for our patients, at most equivalent to $20 \mathrm{Cal} /$ day. The body store of carbohydrate is therefore negligible as a source of calories, except for very short periods. 
Diet. For the most part the diet contained about $400 \mathrm{Cal}$./day provided by about $25 \mathrm{~g}$ protein, $40 \mathrm{~g}$ carbohydrate and ${ }_{5} \mathrm{~g}$ fat, as already described (Strong et al. 1958). McCance \& Widdowson's (1946) tables were used to calculate the caloric value of the diets and the protein intake. The use of tables for this purpose rather than chemical analysis of duplicate samples of the diet inevitably introduces errors: but on the reducing regimen the diet supplied less than $20 \%$ of the energy output, the remainder coming from the patient's own tissues. Even if the tables introduced an error of $15 \%$ (certainly a maximum figure), it would only amount to $60 \mathrm{Cal}$./day, which is smaller than the error involved in calculating the total energy derived from the breakdown of the tissues each day. Passmore, Meiklejohn, Dewar \& Thow (1955 $b$ ) found no significant difference between the figures for the $\mathrm{N}$ content of diets when calculated from tables and when determined by chemical analysis.

Recording of physical activities. Each patient kept a diary in which activities over the whole of the $24 \mathrm{~h}$ of each day were noted, as described by Garry, Passmore, Warnock \& Durnin (1955). Activities were divided into four groups and the time spent on each recorded. These activities were (I) lying in bed, (2) sitting, (3) walking, (4) 'up and about'. Walking included only regular exercise. 'Up and about' included time spent in washing and dressing and in carrying out light tasks to help other patients in the wards.

Measurements of metabolic rates. Rates of energy expenditure during each of these four forms of activity were determined by indirect calorimetry at regular intervals throughout each patient's stay in hospital. The Kofranyi-Michaelis respirometer (Müller \& Franz, I952; Orsini \& Passmore, 1951), was used for measuring ventilation rates and collecting samples of expired air. Expired air was analysed in the Haldane apparatus, duplicate analyses being carried out on each sample. For each patient some thirty to fifty measurements of metabolic rates were made covering all four types of activity during the whole period in hospital.

Calculations of daily rates of energy expenditure. The energy spent each day in each activity was calculated by multiplying the time spent by the metabolic cost of that activity. The total energy expenditure was then determined by adding up the energy spent in each activity. Table $\mathbf{I}$, which gives the results for one subject for 3 weeks, illustrates the method. Previous studies using this method (Passmore et al. I955a; Garry et al. 1955) have shown that reliable results can be obtained. Past experience suggests that under the circumstances of the present observations, the errors in estimating daily energy expenditure would be not more than 10 \% and possibly much less.

Errors arise from two sources. First, there may be inaccurate diary keeping by the patients. Each diary was examined by one of us several times each week and difficulties were discussed with the patients. In the first few days appreciable errors may have been present, but all patients soon settled down to the routine. We are satisfied that the diaries were accurately kept and no substantial error arose from this source. Secondly, an activity as performed during a metabolic measurement may not be a true sample of how that activity was carried out at other periods of the day. It was not possible, for instance, to see that the patients walked at a standard rate during their 
periods of exercise. However, the number of measurements made on each subject when walking was large and enabled some estimate to be made of the range of variation. Patients were frequently observed when measurements were not being made and there was no reason to suppose that any systematic sampling error was present. No measurements of metabolic rates were made during the night; for the period 'in bed', the metabolic rate was taken to be $90 \%$ of the metabolic rate determined when lying down during the day. The maximum error, so introduced, probably does not exceed 50 Cal./day (Passmore \& Durnin, 1955).

Table 1. Mean daily energy expenditure of subject, Miss McN., for 3 weeks

\begin{tabular}{lccc} 
& \multicolumn{3}{c}{ Week } \\
\cline { 2 - 4 } \multicolumn{1}{c}{ Activity } & I & 2 & 3 \\
& \multicolumn{3}{c}{ Time spent (min) } \\
Lying & 603 & 598 & 632 \\
Sitting & 554 & 528 & 475 \\
Up and about & 114 & 113 & 102 \\
Walking & 169 & 201 & 231 \\
& Calories expended (Cal./min) \\
Lying & $1 \cdot 5 \circ$ & $1 \cdot 45$ & $1 \cdot 40$ \\
Sitting & $1 \cdot 80$ & $1 \cdot 65$ & $1 \cdot 55$ \\
Up and about & $3 \cdot 5$ & $3 \cdot 3$ & $3 \cdot 1$ \\
Walking & $6 \cdot 2$ & $6 \cdot 0$ & $5 \cdot 8$ \\
& Calories expended (Cal./day) \\
Lying & 905 & 867 & 885 \\
Sitting & 997 & 871 & 736 \\
Up and about & 399 & 373 & 316 \\
Walking & 1048 & 1206 & 1340 \\
Total & 3349 & 3317 & 3277
\end{tabular}

Urine. Samples were collected for $24 \mathrm{~h}$ periods and the $\mathrm{N}$ content was determined in duplicate by the micro-Kjeldahl method.

Faeces. These, as soon as passed, were put in a refrigerator and weighed within $24 \mathrm{~h}$. Samples were pooled over a 5-7-day period. A portion was dried and then its $\mathrm{N}$ content determined.

\section{RESULTS}

Table 2 shows the calculated composition of the obesity tissue lost by the seven patients over the whole period on the regimen. Fat varied from 73 to $83 \%$, protein from 4 to $7 \%$ and water from 10 to $23 \%$ of the total weight loss in the different patients. The caloric value of the tissue lost lay between 7000 and $8100 \mathrm{Cal} . / \mathrm{kg}$.

This analysis covering a period of 6 weeks may give, however, a false picture of what is happening at any one time. The results for all the patients were calculated over 5- or 7-day periods. In individual periods for each patient, the nature of the tissue lost showed marked variation from the overall picture given in Table 2. All the basic values from which these variations were calculated are given in Table 3 .

Losses and gains in body water. Table 3 also gives the calculated changes in body 
water. Whereas all the patients lost large quantities of water during the first 5-7 days, these losses were not maintained. Indeed for some periods each patient was actually retaining rather than losing water. Water retention was found in twenty out of the forty-seven periods for which the values were calculated, although body-weight fell in each. Fig. I shows diagrammatically the results for Mrs R. and Miss B. It will be seen that during the Ist week more than half the weight lost by both patients was water. Subsequently, Mrs R. retained water during the 2 nd week, remained in virtual equilibrium during the $3^{\text {rd }}$ and $4^{\text {th }}$ weeks and again retained water in the $5^{\text {th }}$ week. In the last week she lost water, but only sufficient to restore the balance to the level reached at the end of the Ist week. Miss $B$. retained water during weeks 2-5, and at the end of week 6 the total water lost was less than at the end of week $\mathrm{r}$.

Table 2. Percentage composition of obesity tissue lost by seven patients during 40-45 days on the regimen

\begin{tabular}{|c|c|c|c|c|c|c|c|}
\hline Total weight loss $(\mathrm{kg})$ & $\begin{array}{r}\text { Mr I. } \\
13.4\end{array}$ & $\begin{array}{c}\text { Mrs R. } \\
16 \cdot 3\end{array}$ & $\begin{array}{c}\text { Mrs L. } \\
\text { I6.0 }\end{array}$ & $\begin{array}{c}\text { Miss } \mathrm{McN} \\
15^{\circ} \circ\end{array}$ & $\begin{array}{r}\text { Miss B. } \\
13.0\end{array}$ & $\begin{array}{c}\text { Miss M. } \\
17 \cdot 3\end{array}$ & $\begin{array}{l}\text { Mr W. } \\
16.0\end{array}$ \\
\hline \multicolumn{8}{|l|}{ Consisting of: } \\
\hline Fat $(\%)$ & 80 & 79 & 73 & 8I & 83 & 76 & 75 \\
\hline Protein (\%) & 6 & 6 & 4 & 5 & 7 & 4 & 6 \\
\hline Water $(\%)$ & I 4 & I 5 & 23 & 14 & 10 & 20 & 19 \\
\hline $\begin{array}{l}\text { Calorie value (Cal./ } \\
\mathrm{kg} \text { ) of 'obesity } \\
\text { tissue' lost }\end{array}$ & 7700 & 7600 & 7000 & 7700 & 8100 & 7200 & 7200 \\
\hline
\end{tabular}

Losses of fat. Fig. I shows that these were regular and remarkably constant. For instance the fat loss of Miss $\mathrm{McN}$. varied only between an average of $250-305 \mathrm{~g} /$ day during the different weeks. This constancy is a reflection of the regularity with which the schedule of walking was maintained, as shown in Table $x$.

Losses of protein. It is known that the protein content of the body is not fixed, and that a labile store of protein exists (Whipple, I956; Holmes, Jones \& Stanier, I954). The size of this store depends partly on the protein content of the diet. To what extent, if at all, it is altered in obesity is unknown. In some obese persons, especially those who are physically active, there appears to be muscular hypertrophy arising out of the need to move the excess body-weight (McCance \& Widdowson, 1951). Thus, when people gain or lose fat, some corresponding change in the protein content of the body is to be expected. How much protein it is desirable or permissible for any one obese person to lose is a question which cannot be answered easily.

For the most part the diet contained about $4 \mathrm{~g} \mathrm{~N} /$ day (equivalent to about $25 \mathrm{~g}$ protein). In the ist week the loss of $\mathrm{N}$ was usually large and balances varied from -4 to $-9 \mathrm{~g} \mathrm{~N} /$ day, indicating daily losses of from 25 to $60 \mathrm{~g}$ protein. The loss of weight in this week was always high and associated with large losses of water. However, in the different subjects, there was no relation between the weight loss and the size of the negative $\mathrm{N}$ balance.

In subsequent weeks the net $\mathrm{N}$ losses were reduced, but there was no indication that any of the subjects would reach equilibrium on a dietary intake of $4 \mathrm{~g} /$ day. Fig. 2 
Table 3. Mean daily measurements of changes in body-weight, energy balance and nitrogen balance, and the estimated changes in body water of seven patients on the regimen

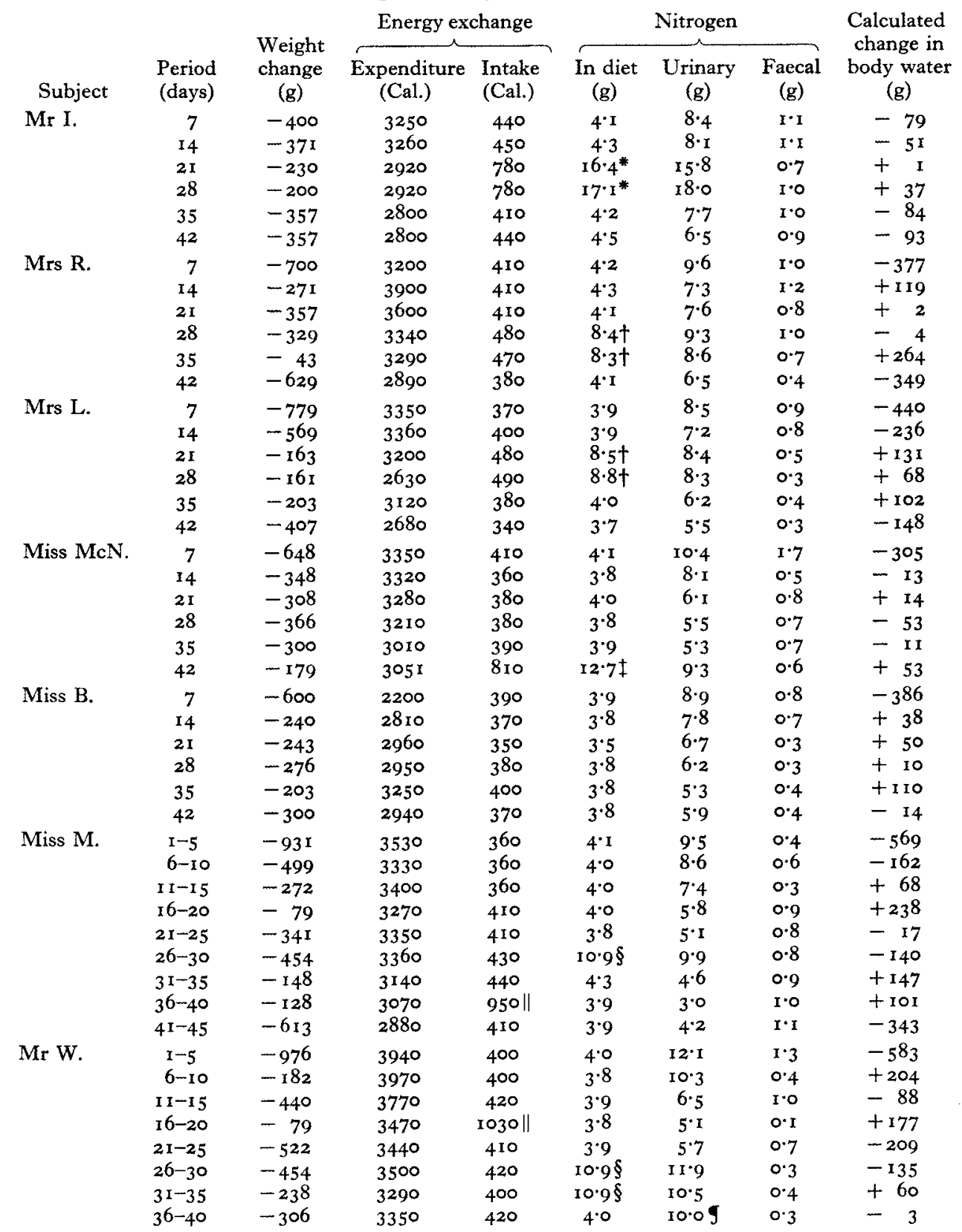

* Diet supplied about: protein 100 , carbohydrate 27 , fat $3 \circ \mathrm{g} /$ day.

$\dagger$ Diet supplied about: protein $5 \circ$, carbohydrate 35 , fat $15 \mathrm{~g} /$ day.

Diet supplied about: protein 80 , carbohydrate, 50 , fat $30 \mathrm{~g} / \mathrm{day}$.

$\S$ I5 g urea given daily.

If Diet supplied about: protein 25 , carbohydrate 200 , fat $10 \mathrm{~g} / \mathrm{day}$.

In this patient the loss in body water for the last three periods was calculated on the assumption that the rate of tissue-protein loss was uniform.

The results of giving urea or a high-carbohydrate diet to two patients are recorded here, but will be discussed in another paper. 
shows the $\mathrm{N}$ balances for three of the subjects. Miss $\mathrm{McN}$. was in positive balance when $\mathrm{N}$ intake was raised to over $12 \mathrm{~g}$ /day. Mrs L. was only in slightly negative balance when $\mathrm{N}$ intake was raised to 8-9g/day. Miss $\mathrm{B}$. remained in negative balance to the extent of about $2 \mathrm{~g} /$ day on an intake of $4 \mathrm{~g}$. The indications are that all of the subjects would have required at least $6-7 \mathrm{~g} \mathrm{~N} /$ day for equilibrium, with a total caloric intake of approximately $400 \mathrm{Cal}$./day.
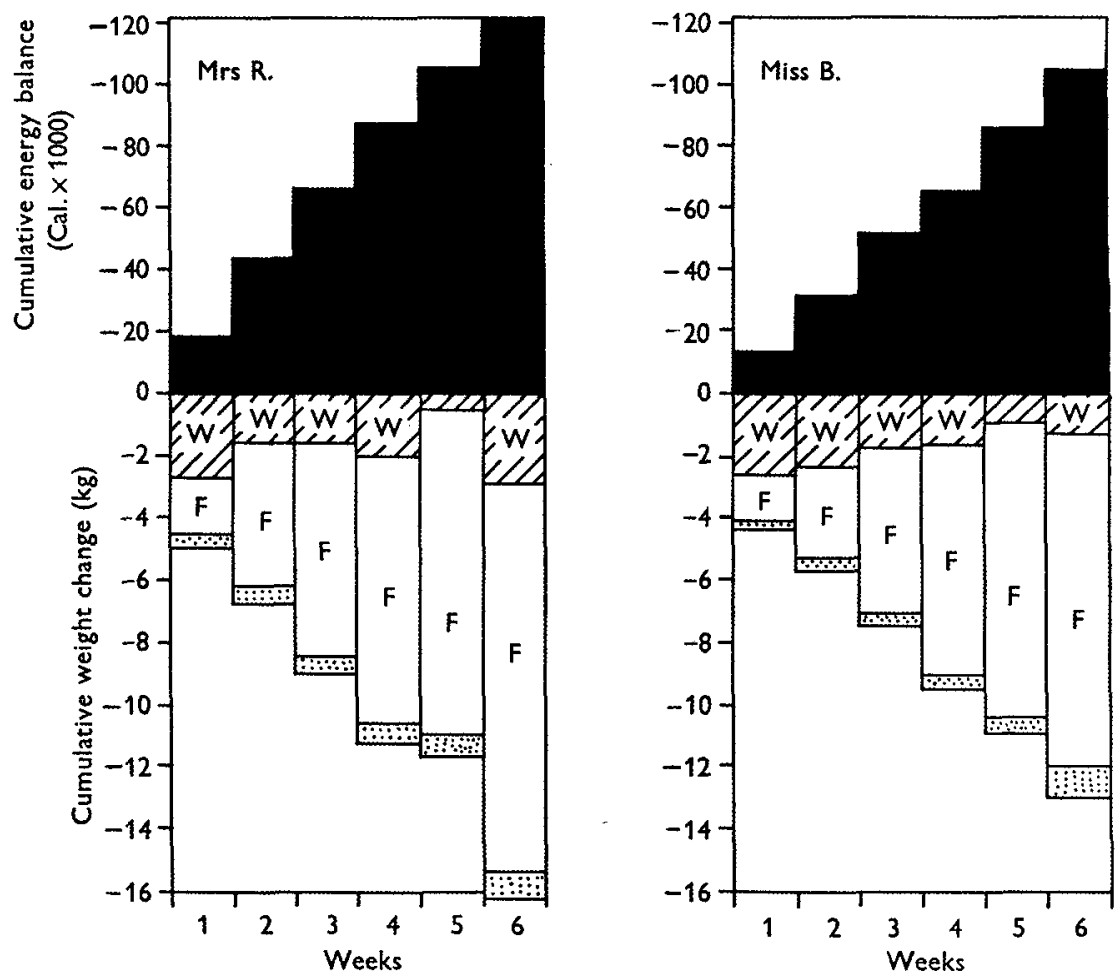

Fig. I. Energy balance and weight loss of Mrs R. and Miss B. for 6 weeks. The cumulative energy deficit is shown above the zero line. The cumulative weight loss and the relative amounts of water, fat and protein are shown below the zero line for the corresponding periods. The blocks represent cumulative changes - the upper solid blocks, the increasing calorie deficit, and the lower blocks the increasing loss of weight. The weight loss is divided into water, fat and protein losses. W, water; F, fat; stipple, protein.

Table 4 shows the estimated total loss of tissue protein by each subject and also the total intake of protein in the diet. In view of the uncertainty about the extent of the protein stores in obese patients, it might be thought that the larger losses may have led to undue depletion and a consequent fall of serum-albumin levels and retention of water. This point was not investigated, except in Miss B. At the end of the 6 weeks, when her estimated loss of tissue protein was $920 \mathrm{~g}$, her serum-protein concentration was within the normal range (total proteins $7.3 \mathrm{~g}$, albumin $4.8 \mathrm{~g} / \mathrm{ro0} \mathrm{ml}$.) and the electrophoretic pattern was normal.

In other obese patients, not fully reported here, there were marked differences in $\mathrm{N}$ excretion. Thus, Mrs D., aged $5^{\circ}$, had been almost immobilized for many years by 
osteo-arthritis and obesity. At a time when she weighed $120 \mathrm{~kg}$, she was given a diet of $400 \mathrm{Cal}$./day containing $5 \mathrm{~g} \mathrm{~N}$. For several weeks she lived on this diet and excreted only $5^{-6} \mathrm{~g} \mathrm{~N}$ daily. On the other hand, T., an active man aged 24 , weighing $147 \mathrm{~kg}$, excreted when on a similar diet $12-16 \mathrm{~g} \mathrm{~N}$ daily in the urine for the first 3 weeks. At the end of 5 weeks his daily urinary output of $\mathrm{N}$ was still between 8 and $12 \mathrm{~g}$. During this time he took long walks and lost $15^{\circ} 9 \mathrm{~kg}$ weight, of which at least $1.5 \mathrm{~kg}$ was protein.
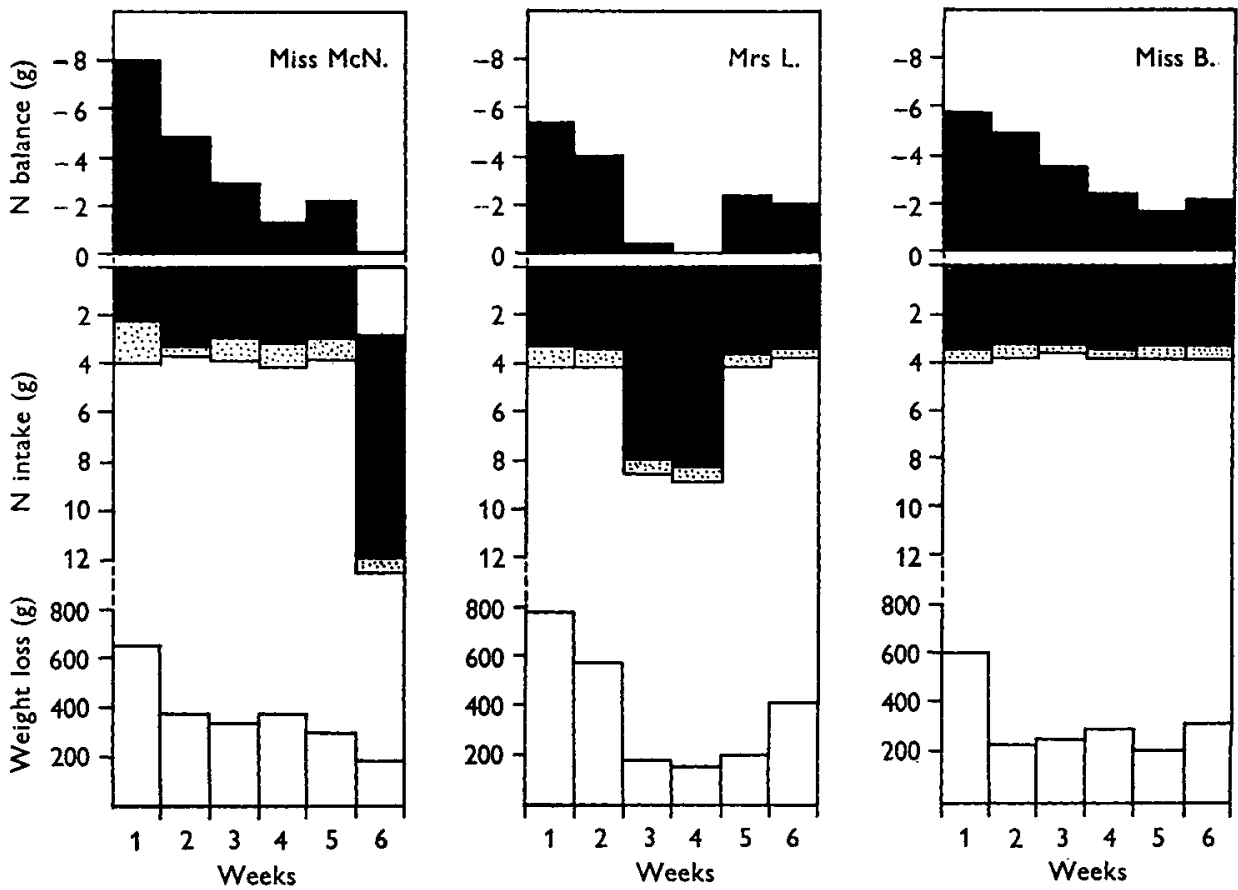

Fig. 2. Mean daily nitrogen balance and weight loss for each week of three subjects. Intake is read from the zero line downwards. Excess of output over intake is shown as the blocked area above the zero. Solid blocks, urinary nitrogen; stippled blocks, faecal nitrogen.

Table 4. Total dietary protein and estimated loss of tissue protein of seven patients for the $40-45$ days of the observation period

Dietary protein

(g)

MrI.

Mrs R.

Mrs L.

Miss $\mathrm{McN}$.

Miss B.

Miss M.

$\mathrm{Mr}$ W.
2210

1460

1440

1410

990

1120
Loss of tissue

protein (g)

$$
\begin{aligned}
& 860 \\
& 900 \\
& 640 \\
& 760 \\
& 920 \\
& 700 \\
& 990
\end{aligned}
$$

Obese patients vary greatly in their need for dietary protein to maintain $\mathrm{N}$ equilibrium and also in the size of the labile protein store. To estimate these factors requires several weeks of detailed study for each patient.

The $\mathrm{N}$ balances take no account of two possible sources of error. First, some $\mathrm{N}$ will 
have been lost in the sweat and in the shedding of cutaneous epithelium and the growth of hair. Holmes et al. (1954) discuss these losses and point out the impossibility of measuring them accurately. They probably amount to between $I$ and $2 \mathrm{~g} /$ day. Their omission makes the negative $\mathrm{N}$ balance shown in Fig, 2 and the protein losses recorded in Table 3 slight understatements. Secondly, no allowances have been made for a possible fall in the non-protein $\mathrm{N}$ in the body fluids. Such a fall would reduce the estimates of body protein lost, but spread over 40 days this error, if indeed it exists, must be very small.

Caloric value of obesity tissue. The variations in water loss alter this value greatly. The overall figure of 7000-8000 Cal./kg of obesity tissue, which was found for all the patients, masks the weekly changes. During the ist week, when water losses were high, the values were less than $5000 \mathrm{Cal} . / \mathrm{kg}$. In subsequent weeks, they were much greater and, when water was being retained, over ro,000 Cal./kg. Keys \& Brožek (r953) calculated the change in body composition in a group of mental patients, whose metabolism appeared to be normal during a period of overfeeding. They calculated that the mean calorie value of the obesity tissue gained was $6700 \mathrm{Cal} . / \mathrm{kg}$. Subsequently, in a study of young men on a restricted ration, Brožek, Grande, Taylor, Anderson, Buskirk \& Keys (1957) reported values for the tissue lost varying between 2600 and $8700 \mathrm{Cal} . / \mathrm{kg}$.

Obesity tissue obviously varies in composition in different circumstances. In response to a period of caloric imbalance, the human body does not gain or lose weight by laying down or discarding tissue of fixed chemical composition. The nature of the obesity tissue lost or gained depends upon the previous state of nutrition and perhaps on the amount of physical exercise taken. It will also vary in different subjects. The concept of obesity tissue is useful, and further investigations of the variations in its chemical composition would be valuable.

\section{DISCUSSION}

Two main conclusions can probably be drawn from the results. First, at the beginning of treatment, the patients had a labile portion of water (about 2-41.) which was readily lost during the first few days on the reducing regimen (initial dehydration). Secondly, after this early loss, subsequent water losses were small and all patients gained water for some period (secondary water retention). This retention of water took place at times when fat and protein continued to be lost.

The initial dehydration may well be due to the change from a mixed diet with a metabolic mixture predominantly derived from carbohydrate to semi-starvation with a metabolic mixture mostly from endogenous fat. It is well known to paediatricians (Holt, 1957) that when infants are transferred from a high-carbohydrate to a high-fat diet they lose weight and this weight is at once regained when the transfer is reversed. These changes are attributable to changes in body-water content. Similar changes may occur in adults. Thus Benedict \& Milner (1907) studied one subject doing hard muscular work, whilst living in a calorimeter chamber. For 3 days on a high-carbohydrate diet, with a net caloric value of $4276 \mathrm{Cal}$./day, the subject gained $184 \mathrm{~g}$ in weight, and the measured gain in body water was $496 \mathrm{~g}$. For the next 3 days he 
continued the same regimen with a high-fat diet ( $4407 \mathrm{Cal} . /$ day). On these 3 days he lost $274 \mathrm{I} \mathrm{g}$ in weight, of which $2718 \mathrm{~g}$ were shown to be water. Perhaps the adult body may require $2-41$. more body water whilst metabolizing carbohydrate rather than fat. This hypothesis is consistent with the observations of the great losses of body-weight at the beginning of a period of total starvation (Johansson, Landergren, Sondén \& Tigerstedt, 1897; Cathcart, 1907) and the initial loss of weight of the arctic explorer Stefansson and his colleague when they adopted an exclusively meat diet (McClellan \& Du Bois, 1930). Kekwick \& Pawan (1956) also showed that over periods of $5^{-7}$ days obese persons lost most weight on a high-fat diet, but little on an isocaloric high-carbohydrate diet.

Severe starvation does not appear to be necessary for this initial dehydration to occur. An obese patient (not otherwise reported here) Mrs G., aged 50, weight $120 \mathrm{~kg}$, was admitted to hospital and put on a diet providing $1980 \mathrm{Cal} /$ day. For a week she seldom left the ward and spent most of her time in bed: yet she lost $\mathrm{r} \cdot 6 \mathrm{~g} \mathrm{~kg}$ weight, of which $1.05 \mathrm{~kg}$ was estimated to be water. Shorvon \& Richardson (1949) have studied patients with obesity associated with severe psychological disturbances. They found that after psychotherapy there might be a sudden loss of weight $(5-10 \mathrm{~kg})$ without any dietary treatment, and suggested that the 'tension' associated with psychological strains may have led to the accumulation of excess quantities of water, which were rapidly eliminated when the 'tension' was relieved by treatment. It is possible that loss of water is a frequent reaction of the body to any sudden change in either physical environment or psychological state. Differences between the temperature in the hospital ward and in the patients' homes cannot be excluded as a factor which might have contributed to the initial dehydration. But we have no reason to suppose that these differences were either large or important.

Secondary water retention occurring in obese patients on a reducing regimen might be of similar origin to the water retention that occurs in normal people during chronic semi-starvation giving rise to famine oedema. Famine oedema has a large literature, which has been reviewed by McCance ( $195^{1}$ ). The oedema is due to accumulation of extracellular fluid, the cause of which is not known. McCance concludes that there is no evidence that the oedema arises as a result of renal failure or hormonal disturbance. A low level of serum albumin can be at most a contributory factor. Youmans, Wells, Donley \& Miller (1934) first suggested that when there is tissue wasting, after a time the elasticity of the skin is not sufficient to maintain the tissue tension. The body may become 'too small for the skin' and water may be retained to keep up the normal tension. Unfortunately, experimental support for this hypothesis is hard to obtain owing to the difficulties of getting true readings for tissue tensions. It might well be that the laxity of the skin after an initial loss of weight in the obese leads to a fall in tissue tension and subsequent retention of water.

The changes in total body water are brought about by variations in fluid intake and in fluid excretion both by the kidneys and in the evaporative water loss. We have measured the total intake of water and the output through the various channels in five of the patients. The results, together with the sodium and potassium exchanges will be presented in a subsequent paper. 


\section{SUMMARY}

x. The chemical composition of the tissue lost by seven obese patients on a reducing regimen has been calculated.

2. Over a period of 6 weeks fat formed $73-83 \%$ of the weight lost, protein $4-7 \%$ and water $10-23 \%$.

3. In the first few days on the regimen each patient lost large amounts of body water, up to 2-4l. (initial dehydration). Subsequently, water losses were much reduced and each patient was found to be retaining water for periods lasting several days (secondary water retention).

We are indebted to Miss J. Halley, Chief Dietician, for much help; to Miss N. Stokoe, B.Sc., Dr Helen Stojicevic and Mr D. Shirling for assistance with the chemical analyses; to Sisters MacDonald and MacLeod for their careful supervision of these patients. We wish to thank the Medical Research Council for a personal grant to one of us (F.J.R.) and also for an expense grant.

\section{REFERENCES}

Benedict, F. G. \& Milner, R. D. (I907), Bull. U.S. Off. Exp. Sta., no. I75.

Brožek, J., Grande, F., Taylor, H. L., Anderson, J. T., Buskirk, E. R. \& Keys, A. (1957). F. appl. Physiol. 10, 412.

Cathcart, E. P. (1907). F. Physiol. 35, 500.

Garry, R. C., Passmore, R., Warnock, G. M. \& Durnin, J. V. G. A. (1955). Spec. Rep. Ser. med. Res. Coun., Lond., no. 289 .

Holmes, E. G., Jones, E. R. \& Stanier, M. W. (1954). Brit. F. Nutr. 8, 173 .

Holt, L. E. (1957). F. Amer. med. Ass. 164, 1890.

Johansson, J. E., Landergren, E., Sondén, K. \& Tigerstedt, R. (1897). Skand. Arch. Physiol. 7, 29.

Kekwick, A. \& Pawan, G. L. S. (1956). Lancet, 271, I 55.

Keys, A. \& Brožek, J. (1953). Physiol. Rev. 33, 245.

McCance, R. A. (195I). In Spec. Rep. Ser. med. Res. Coun., Lond., no. 275, p. 21.

McCance, R. A. \& Widdowson, E. M. (1946). Spec. Rep. Ser. med. Res. Coun., Lond., no. 235, 2 nd ed.

McCance, R. A. \& Widdowson, E. M. (195I). Proc. roy. Soc. B, 138, I15.

McClellan, W. S. \& Du Bois, E. F. (1930). F. biol. Chem. 87, 65 I.

Müller, E. A. \& Franz, H. (1952). Arbeitsphysiologie, 14, 499.

Orsini, D. \& Passmore, R. (1951). F. Physiol. 115, 95.

Passmore, R. \& Durnin, J. V. G. A. (1955). Physiol. Rev. 35, 80 I.

Passmore, R., Meiklejohn, A. P., Dewar, A. D. \& Thow, R. K. (1955a). Brit. F. Nutr. 9, 20.

Passmore, R., Meiklejohn, A. P., Dewar, A. D. \& Thow, R. K. (1955b). Brit. F. Nutr. 9, 27.

Shorvon, H. J. \& Richardson, J. S. (1949). Brit. med. F. ii, 951.

Strong, J. A., Passmore, R. \& Ritchie, F. J. (1958). Brit. $\mathscr{F}$. Nutr. 12, 105.

Whipple, G. H. (1956). The Dynamic Equilibrium of Body Proteins, p. 9. Springfield, Illinois: C. C. Thomas.

Youmans, J. B., Wells, H. S., Donley, D. \& Miller, D. G. (1934). F. clin. Invest. 13, 447. 